\title{
SYSTEMATIC REVIEW WITH META-ANALYSIS OF OBESITY AS RISK FACTOR OF COVID-19 RELATED MORTALITY
}

Achmad Ilham Rizwani' ${ }^{1}$, Syarif Syamsi Ahyandi' ${ }^{1}$, Nanning Naimatuningsih ${ }^{1}$, Endy Novryan Ridwan', Rani Nurvita1, Nurun Nujum', Muhammad Hammam Mahrus ${ }^{1}$, Lilik Djuari*2 ${ }^{-1}$

${ }^{1}$ Clinical clerkship in Faculty of Medicine, Universitas Airlangga, Surabaya, Indonesia, ${ }^{2}$ Public Health Department, Faculty of Medicine, Universitas Airlangga, Surabaya, Indonesia

\begin{tabular}{l} 
ABSTRACT \\
\hline A person with obesity has a high risk of getting a severe \\
complication of COVID-19. This is related to the increasing of \\
chronic illness cases caused by obesity. Obesity itself has been \\
known to take part in the disruption of the human immune \\
system. A person with obesity will be more susceptible to the \\
infection and is suspected to be one of the risk factors that cause \\
death in COVID-19. This study used observational analysis with \\
a systematic review method and continued with Meta-Analysis.
\end{tabular} This study has been held at the Public Health Department of Faculty of Medicine, Universitas Airlangga, Surabaya, in July 2020. The data sources of this study come from online literature, such as published journals that match our inclusion criteria. The inclusion criteria for this study were journals that study the relation of obesity and mortality in COVID-19 cases, journals with a cross-sectional design, journals that used samples age $>18$ y.o., and journals that used BMI as the obesity classification. Five journals matched our criteria and were analyzed in this study. Four of 5 journals show that there is a relationship between obesity and mortality of COVID-19. There are 2133 subjects with COVID-19, and 361 of them have obesity. There are 1861 subjects with COVID-19 who are not dead; 1567 of them don't have obesity. An analytic study with a random effect model shows that obesity is the risk factor of mortality in COVID-19 cases $(O R=2.041 ; 95 \%$ CI 1.027-4.058). It also shows that there is a significant relationship between obesity and mortality in COVID-19 cases ( $p=0.042)$. Most journals analyzed with a systematic review and meta-analysis in this study show that obesity is the risk factor of mortality in COVID-19 cases.

\section{ARTICLE HISTORY}

Received: June 23, 2021

Revised: August 7, 2021

Accepted: August 25, 2021

Published: October 31, 2021

(Online)

doi: $10.20473 /$ jcmphr.v2i2.26038

\section{KEYWORDS}

COVID-19; obesity; mortality; health risk

\section{CORRESPONDINIG}

\section{AUTHOR}

Lilik Djuari

\lilikdjuari@gmail.com; lilik-d@fk.unair.ac.id Public Health Department, Faculty of Medicine, Universitas Airlangga, Surabaya, Indonesia, Jl. Mayjend Prof. Dr. Moestopo 47, Surabaya, Indonesia

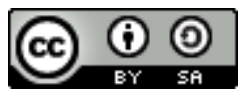

\section{INTRODUCTION}

Coronavirus Disease 2019 (COVID-19) is a disease caused by novel Coronavirus. It first happens in Wuhan, China, as pneumonia with unknown etiology. ${ }^{1}$ Later, the etiology of COVID-19 has been identified as Severe Acute Respiratory Syndrome Coronavirus-2
(SARS-CoV-2). WHO reports that the global COVID-19 cases until 19 July 2020 have reached 14.043.176 confirmed cases, and 597.583 have been reported dead. The global Case Fatality Rate (CFR) of COVID19 is $4.3 \%$. Meanwhile, in Southeast Asia, the confirmed COVID-19 cases reach 1.391.047 with a CFR of $2.4 \% .^{2}$ 
The Ministry of Health of the Republic of Indonesia reports that COVID-19 cases in Indonesia until 20 June 2020 have reached 88.214 confirmed cases with a CFR of $4.8 \% .^{3}$

Obesity increases the risk of chronic illnesses, such as type-2 diabetes mellitus, cardiovascular disease, cancer, disability, and depression.

A person with obesity has a high risk of getting severe complications in the COVID19 cases. This is related to the increasing in chronic illness cases caused by obesity. In the intensive care unit, a person with severe obesity has quite a difficult level of patient management, and it is challenging for medical personnel. ${ }^{4}$ A study in New York shows that most of the COVID-19 patients that need to be administered to the health service are those who have old age $(>65$ y.o.) and obesity. ${ }^{5}$ Recent study in England also shows that patients with IMT $<20$ $\mathrm{kg} / \mathrm{m}^{2}$ (underweight) and IMT $>28 \mathrm{~kg} / \mathrm{m}^{2}$ (obese) have high risk to get severe COVID-19 outcome. ${ }^{6}$ Besides having the risk of increasing the severity of COVID-19 cases, obesity has also taken part in the disruption of the human immune system, leading patients to become more susceptible to infection and is suspected to be the risk factor of mortality COVID-19 cases. $^{7}$

Based on the problems shown above, we are interested in studying obesity as one of the risk factors of COVID-19 related mortality. The method of this study uses systematic review and meta-analysis. We hope this study can be used as a reference to manage this COVID-19 pandemic.

\section{MATERIALS AND METHODS}

The journals used in this study were acquired from search engines such as Google, Google Scholar, and Pubmed. We search the journals in the search engine with this keyword: the relation between obesity and mortality in COVID-19 patients. We limit that only free international journals with the English language published in 2020 can be used in this study.

The title and abstract of each journal were screened. Only journals relevant to this study were selected. The duplicate journals were excluded. The selected journals were then read entirely to determine their compliance with these study inclusion criteria. The literature research strategy diagram can be seen in Figure 1.

\section{Data Selection Criteria}

The inclusion criteria used in this study are journals contain data on obesity and COVID-19 mortality, journals with a crosssectional design, journals that use subjects aged $\geq 18$ years old, and journals that use $\mathrm{BMI}$ as their obesity classification.

\section{Data Extraction}

The data were extracted from the journals which match up with these study inclusion criteria. The data obtained consists of author names, research year, research location, research subjects, inclusion criteria, result, and conclusion of the research.

\section{RESULTS}

\section{Study Characteristics}

The result of the study of 5 journals obtained 2133 subjects with the least subjects are 107 subjects, and the highest is 928 subjects. Data collection in all studies regarding the relationship between obesity and mortality of COVID-19 used was carried out in the timeframe of 2020 and had a cross-sectional study design. Subjects used are males and females aged $\geq 18$ years old.

\section{Analysis}

Four of the five journals used in this study conclude a significant relationship between obesity and mortality in COVID-19. Those 4 journals data were obtained from a random population group in specific 
healthcare facilities or places, so it can plenty describe the global situation nowadays.

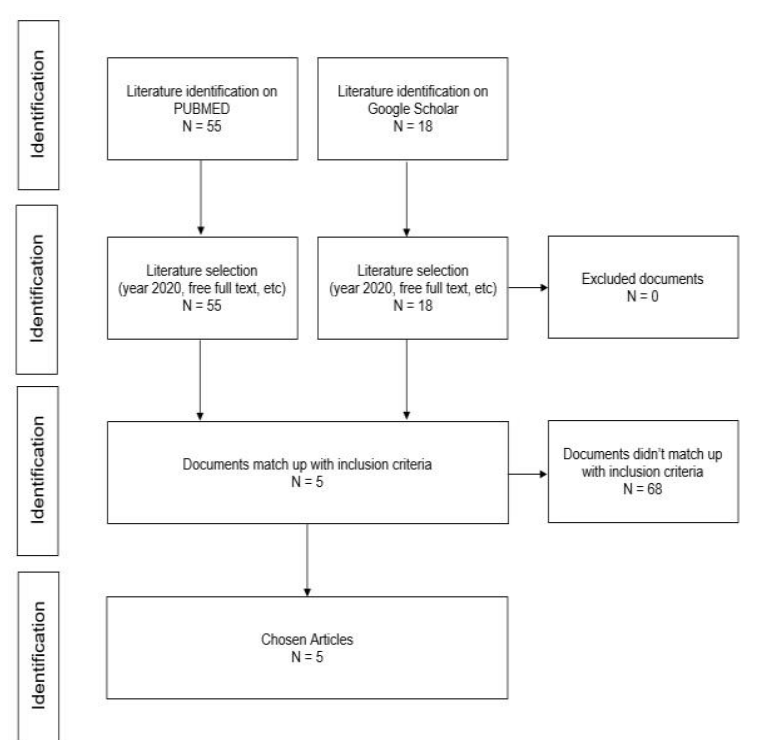

Figure 1. Literature research strategy.

Besides, one journal states that obesity does not significantly relate to COVID-19 mortality in COVID-19 patients with malignancy. Many factors affect the mortality of COVID-19 patients with malignancy rather than obesity itself.

Meta-Analysis of those five journals shows that obesity is the risk factor of mortality in COVID-19 (OR $=2.041 ; 95 \% \mathrm{CI}=1.027-$ 4.058). There is also a significant relationship between obesity and COVID-19 mortality, proven by the $\mathrm{p}$-value $=0.042$.

\section{DISCUSSION}

Obesity is a risk factor for various diseases, including COVID-19. The research results in the previous section found that obesity is a risk factor for the mortality of COVID-19 with $\mathrm{OR}=2.041 ; 95 \% \mathrm{CI}=1.027-4.058$. The $p$-value in this study was 0,042 $(p<0.05)$; these results indicate that this study is significant. The odds ratio obtained in this study illustrates that obese COVID19 patients have a risk of mortality two times higher than the non-obese group.
Research by Cai et al., found that obese men compared to non-obese were 5.66 times more likely to fall into severe COVID-19 infection (OR 5.66; 95\% CI 1.80-17.75; $\mathrm{p}=$ $0.003)$. In the same study, one in three patients who died were obese patients. ${ }^{8}$

Where Escalera-Antezana, who has researched on the first 107 cases of COVID19 in Bolivia, found that age 60, hypertension, chronic heart failure, diabetes, obesity, and the need for ICU are significant risk factors for COVID-19 mortality. ${ }^{9}$

Giacomelli et al. conducted a study of mortality in the first 30 days of treatment in cases of the first wave of COVID-19 in Italy and found that the elderly and obesity increased the risk of death. ${ }^{10}$

Rottoli et al. who conducted a study to determine the relationship between obesity and the severity of COVID-19 found that obesity is a risk factor that can increase the risk of 2,32 times greater incidence of respiratory failure (OR: 2.32; 95\% CI: 1.31 $-4.09, \mathrm{p}=0.004), 4.96$ times the need for ICU care (OR: 4.96; 95\% CI: 2.53 - 9.74; p $<0.001$ ), and 12,1 times the risk of death (OR: 12.1; 95\% CI: 3.25 - 45.1; p <0.001) in the case of COVID-19. ${ }^{11}$

In a study that focused more on cancer patients with COVID-19 by Kuederer et al., It was found that $12 \%$ of all cancer patients who died from COVID-19 were obese. However, from statistical tests on patients with cancer who died from COVID-19, obesity was not a significant factor causing mortality from Covid-19. There are still many other factors involved in cancer patients, such as the result of cancer itself and the treatment being carried out. ${ }^{12}$

The study we conducted is still in line with the five studies we used for further analysis. Nearly all studies support that obesity is a 
factor in the severity of mortality of COVID-19 cases. Apart from obesity, it was mentioned above that there are other risk factors, including old age, diabetes, and hypertension.

The pathophysiology of obesity as a mortality factor from COVID-19 is not yet clear; however, several theories try to explain the course of COVID-19 in obese patients.

Obesity affects various body systems related to the pathogenesis of COVID-19. People with obesity have reduced lung capacity and are more prone to respiratory infections. The lungs of obese people tend to be more restrictive or have more difficulty expanding so that vital lung capacity is reduced. ${ }^{13}$ This reduced vital lung capacity can be fatal when we are in a state of increased oxygen demand, for example, in pneumonia. Obesity can exacerbate the state of respiratory failure.

Proinflammatory cytokine will be triggered by the excess of adipose cells in an obese individual, which will cause the inflammation process to happen. Obesity itself is a condition with chronic inflammation as a result of this adipose cell stack. ${ }^{14}$ Adipose tissue contains various immune cells such as Th2, M-2, Treg, CD8+, and M-1. Those immune cells in normal conditions always maintain their balanced state. However, in obesity, the immune cells in adipose tissue that role as an anti-inflammation (Th2, M-2, Treg) are reduced, and the pro-inflammation immune cells (CD8+, M-1) are increased. This will lead Adipose tissue to become an inflamed tissue that excessively secretes cytokines. Cytokine storm is suspected to be one of the pathophysiologies of the severity of COVID-19, which will worsen if there is a chronic inflammatory condition, for example, in the case of obesity. ${ }^{15}$
Obesity is often found with bad lipid profiles such as dyslipidemia. Dyslipidemia will increase vascular coagulability and makes blood to be more viscous. This viscous blood condition is causing vascular to become inflamed, including the vascular in lungs. Vascular inflammation caused by hypercoagulation blood is suspected to be one of the causes of severity in COVID-19 cases. ${ }^{16}$

In the lungs, SARS-CoV-2 attacks ACE-2 receptors and makes its amount in the lungs become depleted. The decreasing number of ACE-2 receptors in the lungs will disrupt its function to convert the angiotensin-II into angiotensin. The increasing amount of angiotensin-II in the lungs can causa various problems such as vasoconstriction, oxidation, fibrosis, and lung inflammation that leads to Acute Lung Injury and a respiratory failure. This condition will increase the risk of mortality in COVID-19 patients. $^{16}$

SARS-CoV-2 binds with ACE-2 (Angiotensin-Converting Enzyme-2) receptor to enter the cells. ACE-2 receptors are found in various places inside the human body; one is in Adipose cells. ${ }^{17}$ In obese patients, the number of Adipose cells is increased as well as the ACE- 2 receptors. This condition will make more viruses enter the Adipose cells, leading Adipose cells to become the reservoir of SARS-CoV-2. This condition will increase the viral load in obese patients and eventually lead to higher morbidity and mortality in COVID-19 cases. $^{18}$

In Pancreas, the expression of ACE-2 receptor and SARS-CoV-2 causes dysfunction of the Pancreatic $\beta$-cells that cause increases in blood sugar levels and insulin resistance. ${ }^{19}$ This uncontrolled hyperglycemic condition will increase the severity of COVID-19, especially in diabetes and obese patients. ${ }^{20}$ 
Table 1. Study Characteristics

\begin{tabular}{|c|c|c|c|c|c|c|c|}
\hline & $\begin{array}{l}\text { Author Names } \\
\text { (Year) }\end{array}$ & $\begin{array}{l}\text { Location and } \\
\text { Research Year }\end{array}$ & $\begin{array}{l}\text { Study } \\
\text { Design }\end{array}$ & Inclusion Criteria & $\begin{array}{l}\text { Sample } \\
\text { Size }\end{array}$ & $\begin{array}{c}\text { Statistic } \\
\text { Analysis Result }\end{array}$ & Conclusion \\
\hline 1. & $\begin{array}{l}\text { Cai, Q., et al } \\
(2020)^{9}\end{array}$ & $\begin{array}{l}\text { Shenzen Hospital, } \\
\text { China } \\
\text { in } 2020\end{array}$ & $\begin{array}{l}\text { Cross- } \\
\text { sectional }\end{array}$ & $\begin{array}{l}\text { All of the COVID-19 patients } \\
\text { confirmed with a nasal swab and } \\
\text { quantitative PCR (qPCR) assay in } \\
\text { Shenzhen Hospital, China from } 11 \\
\text { February until } 21 \text { February } 2020\end{array}$ & 383 & $\begin{array}{l}\mathrm{p} \text {-value }=0.007 \\
(\mathrm{p}<0.05) \\
\mathrm{OR}=3.40\end{array}$ & $\begin{array}{l}\text { There is a significant } \\
\text { relationship between } \\
\text { obesity and mortality of } \\
\text { COVID-19 }\end{array}$ \\
\hline 2. & $\begin{array}{l}\text { Escalera- } \\
\text { Antezana, et al. } \\
(2020)^{10}\end{array}$ & $\begin{array}{l}\text { Bolivia } \\
\text { in } 2020\end{array}$ & $\begin{array}{l}\text { Cross- } \\
\text { sectional }\end{array}$ & $\begin{array}{l}\text { All of the COVID-19 patients } \\
\text { confirmed with RT-PCR in Bolivia } \\
\text { from } 2 \text { March until } 29 \text { March } 2020\end{array}$ & 107 & $\begin{array}{l}\mathrm{p} \text {-value }=0.002 \\
(\mathrm{p}<0.05) \\
\mathrm{OR}=12.125\end{array}$ & $\begin{array}{l}\text { There is a significant } \\
\text { relationship between } \\
\text { obesity and mortality of } \\
\text { COVID-19 }\end{array}$ \\
\hline 3. & $\begin{array}{l}\text { Giacomelli et al. } \\
(2020)^{11}\end{array}$ & $\begin{array}{l}\text { Milan, Italy } \\
\text { in } 2020\end{array}$ & $\begin{array}{l}\text { Cross- } \\
\text { sectional }\end{array}$ & $\begin{array}{l}\text { All of the adult COVID-19 patients } \\
\text { confirmed with RT-PCR hospitalized } \\
\text { in Luigi Sacco Hospital, Milan, Italy } \\
\text { between } 21 \text { February and } 19 \text { March } \\
2020\end{array}$ & 233 & $\begin{array}{l}\mathrm{p} \text {-value }=0.0029 \\
(\mathrm{p}<0.05) \\
\text { OR }=2.37\end{array}$ & $\begin{array}{l}\text { There is a significant } \\
\text { relationship between } \\
\text { obesity and mortality of } \\
\text { COVID-19 }\end{array}$ \\
\hline 4. & $\begin{array}{l}\text { Rottoli et al } \\
(2020)^{12}\end{array}$ & Bologna, Italy & $\begin{array}{l}\text { Cross- } \\
\text { sectional }\end{array}$ & $\begin{array}{l}\text { All of the COVID- } 19 \text { patients } \\
\text { confirmed with RT-PCR hospitalized } \\
\text { in Sant'Orsola Hospital, Bologna, } \\
\text { Italy, between } 1 \text { March and } 20 \text { April } \\
2020\end{array}$ & 482 & $\begin{array}{l}\text { p-value }<0.001 \\
\text { OR }=12.1\end{array}$ & $\begin{array}{l}\text { There is a significant } \\
\text { relationship between } \\
\text { obesity and mortality of } \\
\text { COVID-19 }\end{array}$ \\
\hline 5. & $\begin{array}{l}\text { Kuderer et al } \\
(2020)^{13}\end{array}$ & $\begin{array}{l}\text { USA, Canada, } \\
\text { and Spain }\end{array}$ & $\begin{array}{l}\text { Cross- } \\
\text { sectional }\end{array}$ & $\begin{array}{l}\text { All the patients who have the history } \\
\text { of malignancy aged } \geq 18 \text { y.o., } \\
\text { confirmed with SARS-CoV-2 } \\
\text { infection between } 17 \text { March and } 16 \\
\text { April } 2020\end{array}$ & 928 & $\begin{array}{l}p \text {-value }=0.543 \\
(p>0.05) \\
\text { OR }=0.853\end{array}$ & $\begin{array}{l}\text { Ther is no significant } \\
\text { relationship between } \\
\text { obesity and mortality in } \\
\text { COVID-19 patient with } \\
\text { malignancy }\end{array}$ \\
\hline
\end{tabular}


Table 2. A meta-analysis of the relation between obesity and mortality in COVID-19

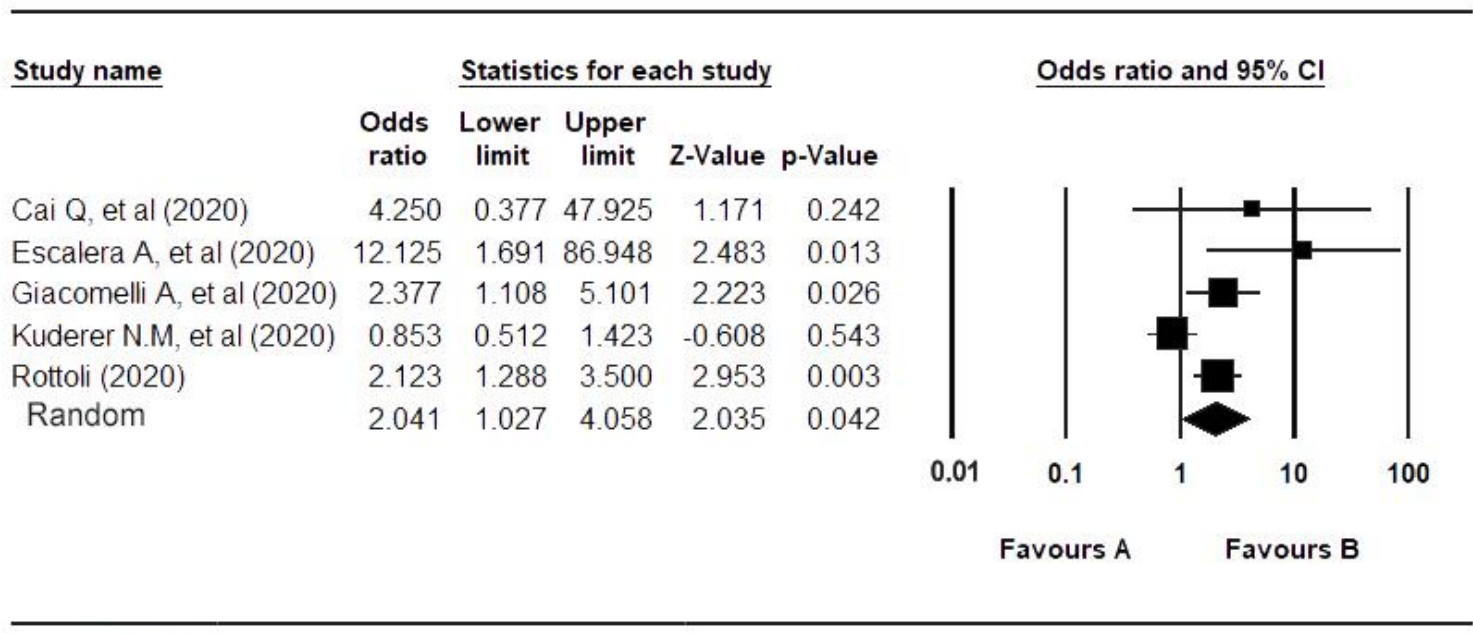

\section{CONCLUSION}

Most of the studies used in this systematic review and meta-analysis show that obesity is associated with increased mortality risk among patients with COVID-19.

\section{REFERENCES}

1. Li Q, Guan X, Wu P, et al (2020). Early Transmission Dynamics in Wuhan, China, of Novel Coronavirus-Infected Pneumonia. New England Journal of Medicine, 382(13), 1199-1207 DOI: 10.1056/NEJMoa2001316.

2. WHO (2020). WHO Coronavirus Disease (COVID-19) Dashboard, https://covid19.who.int/

3. Kementerian RI (2020). Gugus Tugas Percepatan Penanganan COVID-19, https://covid19.go.id/peta-sebaran

4. Hruby A, Hu FB (2015). The Epidemiology of Obesity: A Big Picture. Pharmaco Economics. 33(7), 673-689. DOI: 10.1007/s40273-0140243-x.

5. Finer N, Garnett SP, Bruun JM (2020). COVID-19 and obesity. Clinical Obesity. 10(3), e12365. DOI: https://doi.org/10.1111/cob.12365.

6. Gao M, Piernas C, Astbury NM, et al (2021). The Lancet Diabetes \&
Endocrinology. 9(6), 350-359. DOI: 10.1016/S2213-8587(21)00089-9.

7. Kassir R (2020). Risk of COVID-19 for patients with obesity. Obes Rev. 21(6), e13034. DOI: 10.1111/obr.13034.

8. Cai Q, Huang D, Ou P, et al (2020). COVID-19 in a designated infectious diseases hospital outside Hubei Province, China. Allergy, 75(7), 17421752. DOI: 10.1111/all.14309.

9. Escalera-Antezana JP, Lizon-Ferrufino NF, Maldonado-Alanoca A, et al (2020). Clinical features of the first cases and a cluster of Coronavirus Disease 2019 (COVID-19) in Bolivia imported from Italy and Spain. Travel Med Infect Dis, 35, 101653. DOI: 10.1016/j.tmaid.2020.101653.

10. Giacomelli A, Ridolfo AL, Milazzo L, et al (2020). 30-day mortality in patients hospitalized with COVID-19 during the first wave of the Italian epidemic: A prospective cohort study. Pharmacol Res. 158, 104931.

DOI: $10.1016 /$ j.phrs.2020.104931.

11. Rottoli M, Bernante P, Belvedere A, et al (2020). How important is obesity as a risk factor for respiratory failure, intensive care admission and death in hospitalised COVID-19 patients? Results from a single Italian centre. European Journal of Endocrinology. 
183(4), 389-397. DOI: 10.1530/eje-200541 .

12. Kuderer NM, Choueiri TK, Shah DP, et al (2020). Clinical impact of COVID-19 on patients with cancer (CCC19): a cohort study. The Lancet. 395(10241), 1907-1918. DOI: 10.1016/S01406736(20)31187-9.

13. Dixon AE, Peters U (2018). The effect of obesity on lung function. Expert Rev Respir Med. 12(9), 755-767. DOI: 10.1080/17476348.2018.1506331.

14. Marazuela M, Giustina A, PuigDomingo M (2020). Endocrine and metabolic aspects of the COVID-19 pandemic. Reviews in endocrine \& metabolic disorders. 21, 495-507. DOI: 10.1007/s11154-020-09569-2.

15. Mohammad S, Aziz R, Al Mahri S, et al (2021). Obesity and COVID-19: what makes obese host so vulnerable? Immun Ageing. 18(1), 1.

DOI: $10.1186 / \mathrm{s} 12979-020-00212-x$.

16. Sanchis-Gomar F, Lavie CJ, Mehra MR, et al (2020). Obesity and Outcomes in COVID-19: When an Epidemic and Pandemic Collide. Mayo
Clinic Proceedings, 95(7), 1445-1453. DOI: 10.1016/j.mayocp.2020.05.006.

17. Cava E, Neri B, Carbonelli MG, et al (2021). Obesity pandemic during COVID-19 outbreak: Narrative review and future considerations. Clinical nutrition (Edinburgh, Scotland), 40(4), 1637-1643.

DOI: 10.1016/j.clnu.2021.02.038.

18. Huang Y, Lu Y, Huang Y-M, et al (2020). Obesity in patients with COVID-19: a systematic review and meta-analysis. Metabolism: clinical and experimental, 113, 154378-154378. DOI: 10.1016/j.metabol.2020.154378.

19. Sattar N, McInnes IB, McMurray JJV (2020). Obesity Is a Risk Factor for Severe COVID-19 Infection. Circulation, 142(1), 4-6. DOI: 10.1161/CIRCULATIONAHA.120.047 659.

20. Popkin BM, Du S, Green WD, et al (2020). Individuals with obesity and COVID-19: A global perspective on the epidemiology and biological relationships. Obesity Reviews. 21(11), e13128.

DOI: https://doi.org/10.1111/obr.13128. 